\title{
The Ethiopian wolf - an endangered endemic canid
}

\author{
Dada Gottelli and Claudio Sillero-Zubiri
}

The Ethiopian wolf is a social canid endemic to the highlands of Ethiopia. Today perhaps only 500 individuals survive, making it the world's rarest and probably most endangered canid. Its range has already been reduced and it is threatened by further loss of habitat to high-altitude subsistence agriculture and overgrazing by livestock. Today it survives in only six locations, with the largest and probably only genetically viable population being found in the Bale Mountains National Park. The most immediate threats for the survival of Ethiopian wolves are disease, domestic dogs and human persecution. Improved management in Bale and Simien Mountains National Parks and the establishment of a captive-breeding programme are urgently needed to prevent the extinction of this species.

Until as recently as 10,000 years ago (Messerli et al., 1977), the highlands of Ethiopia were widely covered with Afro-alpine moorland and grassland. These habitats generally lacked the herds of large ungulates characteristic of the African plains, but smaller mammals were present in great abundance, particularly mole rats (Rhizomyinae) and grass rats (Murinae). The Ethiopian wolf*, Canis simensis, a specialist rodent hunter also known as the Simien jackal, must have been shaped morphologically by this environment. The species, endemic to Ethiopia, is only one of many that have evolved and persisted in the country because of the sheer size of the mountain massif.

Ethiopian wolves may have never been very abundant, due to their specialized adaptation to Afro-alpine habitat. They occur now only above $3000 \mathrm{~m}$ above sea level in open moorlands with short vegetation. Analysis of their

\footnotetext{
* A recent IUCN Canid Specialist Group meeting decided that the English name of Canis simensis should be the Ethiopian wolf, rather than the Simien jackal or fox, red jackal, or Abyssinian wolf. This decision was prompted by preliminary findings of an ongoing genetic study, which show that Canis simensis is closely related to wolves and very distant from jackals. The species probably reached Africa in the relatively recent past, by a land bridge in the late Pleistocene.
}

diet reveals that they subsist primarily on rodents; interestingly, most of their prey species are also endemic to the Ethiopian moorlands.

With a population of $340-520$ individuals, this distinctive carnivore is considered to be the rarest and most endangered canid in the world and the most endangered in subSaharan Africa. More than half of today's world population live in the Bale Mountains National Park (BMNP) on the south-eastern rim of the Rift Valley where, since 1988, we have been carrying out a field study on the behavioural ecology of the species.

\section{Ecology}

Ethiopian wolves are territorial social canids, organized in multi-male packs of up to 13 adult animals. Average group size is seven ( $t$ 2.2 SD $n=9)$. Adult sex ratio is biased toward males 1.8:1 ( $n=58$, from nine packs). Males do not disperse, whereas females disperse at 2 years of age. Pack home ranges in optimal habitat average $6.4 \mathrm{sq} \mathrm{km}(n=9$ packs; range $=2.4-10.6 \mathrm{sq} \mathrm{km}$ ), and $10-12 \mathrm{sq} \mathrm{km}$ in areas of lower rodent prey productivity $(n=3)$. All pack members participate actively in the defence and marking of the territory and con- 
tribute to the rearing of pups (36 pack/years).

Ethiopian wolves are solitary diurnal predators. Analysis of faecal samples revealed that rodents account for 95.8 per cent of all prey. The endemic giant mole-rat Tachyoryctes macrocephalus is the main food item in the diet, followed by three species of grass rats. Rodent prey can reach astonishing densities. In the Afro-alpine meadows of BMNP rodent biomass was estimated at $3000-4000 \mathrm{~kg}$ per sq $\mathrm{km}$.

\section{Habitat available to the Ethiopian wolf}

The Afro-alpine habitat - characteristically represented by the Sanetti Plateau in Bale Mountains - was geographically widespread during the Pleistocene (Yalden, 1983). During the last glacial period $(70,000-10,000$ years BP) the African tropics were generally colder and drier than at present (Bonnefille et al., 1990); consequently, the moorland zones of East African mountains were about $1000 \mathrm{~m}$ lower 15,000 years ago than they are now (Flenley, 1979). Extrapolation of the present distribution of Afro-alpine habitat in Ethiopia to all land situated up to $1000 \mathrm{~m}$ below its present lower altitudinal limit suggests that up to $100,000 \mathrm{sq}$ $\mathrm{km}$ of habitat may have been available to the Ethiopian wolf and its rodent prey during the last glaciation.

The end of the Pleistocene brought climatic change and the extensive Ethiopian Afroalpine moorlands shrunk to their present state, reducing the habitat available to the Ethiopian wolf by one order of magnitude. Today about 2 per cent (or 22,750 sq km) of the total land area of Ethiopia is above $3000 \mathrm{~m}$ (Yalden, 1983). Of that, less than 10 per cent consists of Afro-alpine steppes or montane grasslands suitable for the Ethiopian wolf, which is now found only in a few localized mountain pockets.

Table 1 summarizes the availability of habitat for the species throughout Ethiopia. Practical constraints did not allow a thorough survey of all areas of Ethiopian wolf habitat, therefore it was assumed that heather moorland habitat was the dominant vegetation between 3400 and $3800 \mathrm{~m}$ and that Afro-alpine meadows were characteristic above $3800 \mathrm{~m}$. This was supported by data collected in Bale Mountains, during visits to some of the locations in Bale, Arssi and Shoa regions, and from the literature (e.g. Scott, 1958; Brown, 1964a, b).

\section{Past and present distribution}

Yalden et al. (1980) was the first attempt to collate all known Ethiopian wolf locations from the literature. With the exception of the population in the Bale Mountains, the Ethiopian wolf is certainly less common than in the past and also has a reduced range (Figure 1). There are no recent records at altitudes below 3000 $\mathrm{m}$, although specimens were collected at 2500 $\mathrm{m}$ from north-west Shoa at the beginning of the century (Yalden et al., 1980). It is probable that the species was restricted altitudinally with increasing agricultural pressure and persecution.

For want of local data on ecology, and absolute distribution and density, it is difficult to

Table 1. Afro-alpine and montane habitat potentially available to the Ethiopian wolf throughout Ethiopia (small isolated mountain peaks not included)

\begin{tabular}{|c|c|c|c|}
\hline \multirow[b]{2}{*}{ Region } & \multirow{2}{*}{$\begin{array}{l}\text { Land } \\
\text { above } \\
3000 \mathrm{~m} \\
(\mathrm{sq} \mathrm{km})\end{array}$} & \multicolumn{2}{|c|}{$\begin{array}{l}\text { Ethiopian wolf } \\
\text { potential habitat }\end{array}$} \\
\hline & & $\begin{array}{l}\text { Above } \\
3400 \mathrm{~m} \\
(\mathrm{sq} \mathrm{km})\end{array}$ & $\begin{array}{l}\text { Above } \\
3800 \mathrm{~m} \\
(\mathrm{sq} \mathrm{km})\end{array}$ \\
\hline Bale* & 4,950 & 1,284 & 420 \\
\hline Wollo & 4,075 & $\sim 1,000$ & $\sim 300$ \\
\hline Shoa* & 3,400 & 112 & - \\
\hline Arssi* & 3,050 & 428 & 117 \\
\hline Gojjam & 2,575 & $\sim 600$ & $?$ \\
\hline Gondar* & 2,475 & 796 & 204 \\
\hline Sidamo & 350 & 50 & - \\
\hline Tigray & 350 & $?$ & - \\
\hline Hararge & 150 & 2 & - \\
\hline Others & 1,375 & $?$ & $?$ \\
\hline Total & 22,750 & $-4,272$ & $\sim 1,041$ \\
\hline
\end{tabular}

* Regions where the species occurs today.

Total land above $3000 \mathrm{~m}$ from Yalden (1983). 


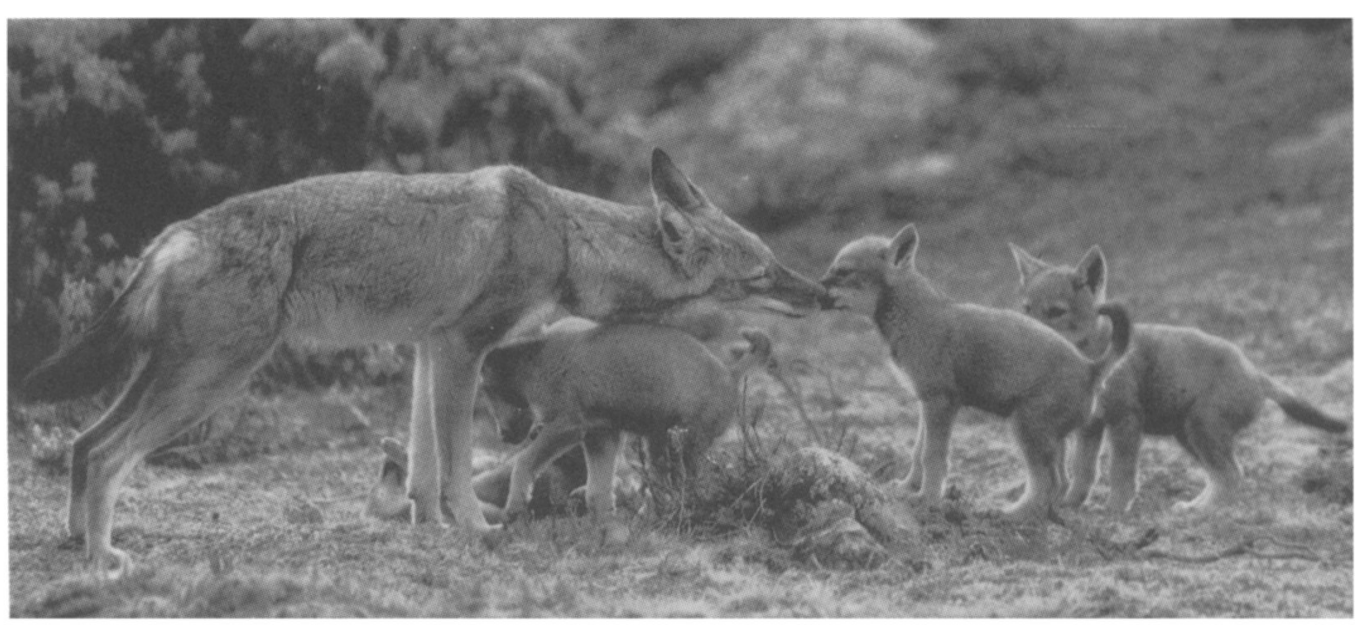

Although a solitary forager subsisting on small rodents, the Ethiopian wolf lives in packs of up to 13 adult animals and has a fascinating social organization (Sillero and Gottelli/WCI).

arrive at population estimates outside BMNP with any accuracy. However, an attempt is made here to estimate the population of adult

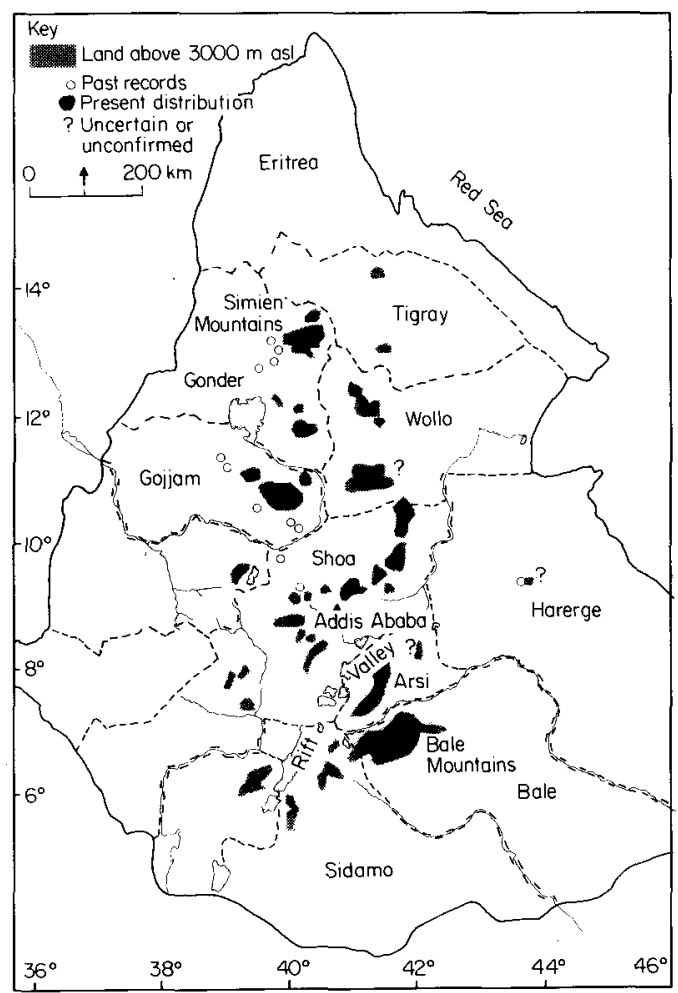

Figure 1. Past and present distribution of the Ethiopian wolf. Past records from Yalden et al. (1980). animals ( $>1$ year old) that probably exist in different locations based on the data on Ethiopian wolf population dynamics obtained in the Bale Mountains. Other factors, such as the extent of suitable habitat remaining and human pressure are also taken into account. The current total population of Ethiopian wolf is likely to be in the order of $340-520$ adult animals (Table 2).

The northern race $C$. s. simensis occurs in isolated populations in Simien and Mount Guna in Gondar Region, and in north-eastern Shoa. Ethiopian wolves have been reported regularly from the Simien Mountains, but due to human persecution they are very secretive and seldom seen. Several sources estimated the population in the 1970 s at 20-30 (e.g. Hurni, 1986). Formerly the species occurred in Gojjam and in western Shoa, but now appears to be extinct in those areas; the last records were in 1932. It is possible that the species may survive in the largely unexplored highlands of western Wollo.

Probably no more than 70-150 animals remain north of the Rift Valley. The causes for this decline and discontinuous distribution are all too apparent considering the history of this region, particularly during the last century. The increase in human population has led to massive expansion of agriculture, high-altitude shifting cultivation, heather fires, collec- 
tion of firewood and overgrazing by livestock.

Most of the Ethiopian wolf's world population lives south-east of the Rift Valley, where the race $C$. s. citernii occurs in the Arssi, Bale and Somkaro mountains. The largest population is that of Bale, where about $1200 \mathrm{sq} \mathrm{km}$ of Afro-alpine habitat constitute the largest range of such habitat on the continent.

\section{The Bale Mountains}

The Bale Mountains are situated in the eastern Ethiopian Highlands along the eastern edge of the Rift Valley. The BMNP covers $2400 \mathrm{sq} \mathrm{km}$ and was established in 1970 in order to conserve the Ethiopian wolf and the endemic mountain nyala, Tragelaphus buxtoni (Hillman, 1986a). It includes the major part of the mountains' high-altitude plateau, over $3500 \mathrm{~m}$ above sea level, as well as the forested slopes to the south down to $1500 \mathrm{~m}$. The climate is characterized by an 8-month rainy season, followed by a 4-month dry season with extremely cold nights and warm days.

Ethiopian wolves are common above 3000 $\mathrm{m}$ and up to the summit of Tullu Deemtu at $4377 \mathrm{~m}$ (the highest mountain in southern Ethiopia), with two areas of concentration: one on the Sanetti Plateau at about $4000 \mathrm{~m}$ and the other in the Web Valley at $3500 \mathrm{~m}$ (Figure 2).

The first estimate for the Bale population was that by J. Malcolm of between 350 and 475 animals (Morris and Malcolm, 1977). Malcolm (1987) revisited Bale and concluded that the population had remained stable or even

Table 2. Summary of Ethiopian wolf populations

\begin{tabular}{|c|c|c|c|c|c|}
\hline \multirow[b]{2}{*}{ Location } & \multicolumn{2}{|c|}{ Habitat available } & \multirow[b]{2}{*}{$\begin{array}{l}\text { Population } \\
\text { estimate }\end{array}$} & \multirow[b]{2}{*}{ Viability } & \multirow[b]{2}{*}{ Threats } \\
\hline & $\begin{array}{l}\text { Total }{ }^{*} \\
(\mathrm{sq} \mathrm{km})\end{array}$ & $\begin{array}{l}\text { Afro-alpine } \\
\text { (sq km) }\end{array}$ & & & \\
\hline \multicolumn{6}{|l|}{ NW of Rift Valley } \\
\hline Simien Mountains NP & 680 & 180 & $35-90$ & $?$ & $\begin{array}{l}\text { Loss of habitat, } \\
\text { persecuted as stock } \\
\text { raiders. Domestic dogs? }\end{array}$ \\
\hline Mount Guna & 110 & $<25$ & $10-20$ & $?$ & Loss of habitat, dogs? \\
\hline \multicolumn{6}{|l|}{ North-east Shoa } \\
\hline Gosh Meda/Ankober & 46 & $<10$ & $10-15$ & $?$ & \multirow{2}{*}{$\begin{array}{l}\text { Loss of habitat, } \\
\text { persecution, } \\
\text { dogs, road kills }\end{array}$} \\
\hline Mahal Meda/Menz & 66 & $<20$ & $10-20$ & $?$ & \\
\hline \multicolumn{6}{|l|}{ SE of Rift Valley } \\
\hline Bale Mountains NP & 1,209 & 646 & $205-270$ & Viable & $\begin{array}{l}\text { Disease, competition and } \\
\text { hybridization with dogs, } \\
\text { road kills, persecution }\end{array}$ \\
\hline \multicolumn{6}{|l|}{ West Bale } \\
\hline $\begin{array}{l}\text { Somkaro/Korduro Mts } \\
\text { Witit'ana Valley }\end{array}$ & $\begin{array}{r}100 \\
55\end{array}$ & 15 & $\begin{array}{l}15-20 \\
10-15\end{array}$ & $\begin{array}{l}\text { Viable }^{+} \\
\text {Viable }^{+}\end{array}$ & $\left\{\begin{array}{l}\text { Domestic dogs, } \\
\text { persecution? }\end{array}\right.$ \\
\hline \multicolumn{6}{|l|}{ Arssi Mountains } \\
\hline Mount Kaka & 110 & 30 & $15-20$ & $?$ & \multirow{2}{*}{$\begin{array}{l}\text { Loss of habitat, dogs? } \\
\text { road kills? }\end{array}$} \\
\hline Mount Chilalo/Ticho & 318 & 87 & $30-50$ & $?$ & \\
\hline Totals & 2,694 & 1,013 & $340-520$ & & \\
\hline
\end{tabular}

* Afro-alpine and sub Afro-alpine habitat potentially available to Ethiopian wolf.

${ }^{\ddagger}$ Believed to be connected genetically with the BMNP population.

Population estimates are informed guesses for all but BMNP. Estimates for Gosh Meda, Mount Kaka, and West Bale Region supported by data gathered during short field visits. 


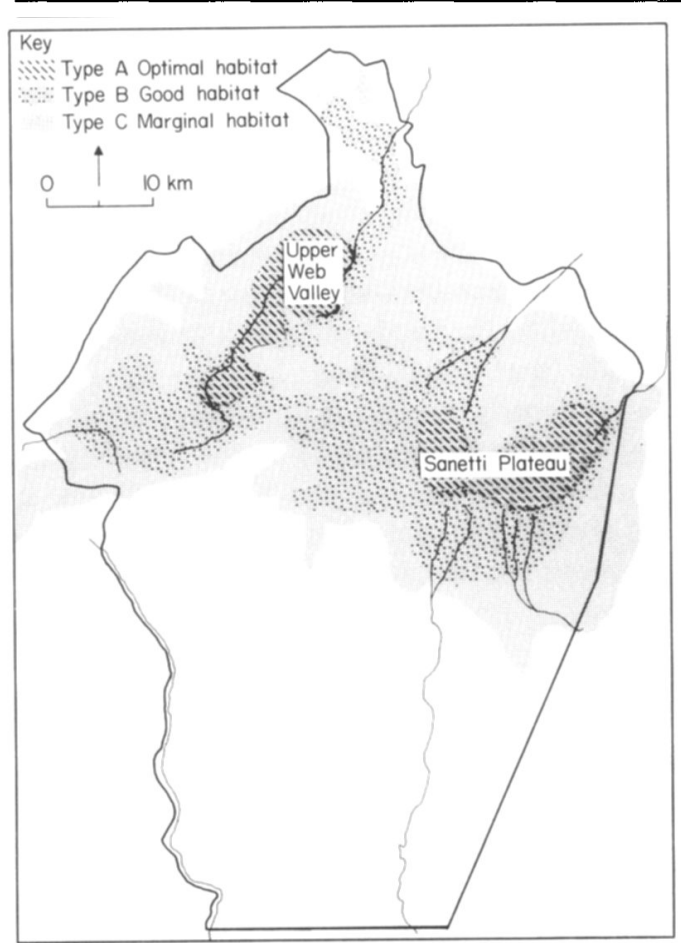

Figure 2. Distribution of the Ethiopian wolf in Bale Mountains National Park showing different degrees of habitat quality for the species.

increased during the previous 10 years, reassessing its size at 450-600. Hillman (1986b) carried out wildlife counts between 1983 and 1986 and estimated the total number of wolves to be around 700 . A questionnaire and interviews with pastoralists living in BMNP suggest Ethiopian wolf numbers increased since the park was established (Gottelli and Sillero-Zubiri, 1990).

During this present study absolute densities of Ethiopian wolf were calculated for different areas and habitat types inside BMNP. The availability of different habitats was estimated from a 1:100,000 map and from evaluation of habitat quality on the ground, based on rodent density, vegetation type and terrain. Habitat available was classified into three categories according to different degrees of habitat quality (Table 3). Based on this classification of habitat types and respective wolf densities the total population of adult animals in BMNP was calculated at $440-470$ during 1990 (SilleroZubiri and Gottelli, 1991). The current popu- lation is estimated at 205-270 (March 1992 densities as in Table 3). Disease and shooting accounted for this dramatic population decline (see below).

The density of Ethiopian wolves is negatively correlated with vegetation height and positively correlated with the density of rodent prey, with the highest concentrations on the Sanetti Plateau and Web Valley. Ethiopian wolves are uncommon in large areas of heather moorlands and on barren peaks where shallow soils prevent high rodent concentrations.

\section{Status}

The Ethiopian wolf is protected by National Law in Ethiopia. The Wildlife Conservation Regulations, 1974, include Canis simensis in the list of protected species. Suitable habitat is protected within two national parks - Simien Mountains and BMNP. The species is listed as endangered in the 1990 IUCN Red List of Threatened Animals (IUCN, 1990). Ginsberg and Macdonald (1990) recommended that its status should remain as endangered until population levels have stabilized and protection of the areas where it occurs are secured. Ethiopian wolves do not appear to be affected by poaching or trade and the species is not listed by CITES; probably it should not be included unless it requires protection from trade in the future.

\section{Threats to the Ethiopian wolf}

\section{Habitat destruction and fragmentation}

Today, the highlands of Ethiopia are among the most densely populated agricultural areas within Africa; rural densities of 47 people/sq $\mathrm{km}$ are typical (Mesfin Wolde-Mariam, 1972). The problems of habitat destruction, soil degradation and high population pressure are persistent; they are concentrated in the north of the country but are spreading south rapidly. Remnants of Afro-alpine ecosystems increasingly resemble islands surrounded by lowland 
areas as ecological boundaries (Hurni, 1986). The potential risk of local extinctions of many endemic species has to be seen in connection with this process of insularisation (Kingdon, 1990).

Unlike the highlands of northern Ethiopia, the Bale Mountains have never been heavily populated. In 1984 an aerial survey showed that an estimated 2500 people were permanently settled in the park, approximately one person per sq $\mathrm{km}$ (Hillman, 1986b). About one-third live in Ethiopian wolf habitat. These people are Oromo pastoralists, depending for their livelihood on cattle and small stock, which they graze in the mountain meadows. In areas below $3500 \mathrm{~m}$ livestock-raising is combined with cultivation of barley. Although the Oromo within the BMNP have coexisted peacefully with the Ethiopian wolf in the past, this is quickly changing.

Extensive overgrazing by cattle probably has a significant unfavourable impact on the rodent populations. For example, Delany studied rodent ecology in the Queen Elizabeth National Park, Uganda, and concluded that the highest populations of rodents occurred where large mammals were least numerous, and that the areas heavily grazed by the latter species had fewer rodents (Delany, 1972). Regular livestock censuses in the Web Valley indicated a maximum of 3000 head of cattle and 220 horses and donkeys using an area of
$70 \mathrm{sq} \mathrm{km}$ at any given time ( $46 \mathrm{head} / \mathrm{sq} \mathrm{km}$ ). Sheep and goats forage on the steep valley sides and ridges. Livestock numbers in the Web Valley are highest during the late wet season when the herds are kept away from the extensive wheat crops in the lowlands. Livestock numbers are lowest in the dry season, when the herds are taken to feed on the fields that have been left to lie fallow. Traditionally, people from all around BMNP take their cattle regularly to the high-altitude mineral springs, but the prolonged stay of livestock by the springs suggests that their use is becoming the excuse for grazing at high altitudes.

\section{Domestic dogs}

Domestic dogs, kept to guard livestock from predators, are present throughout BMNP. Very few dogs are fed or looked after, rather they are feral, living on offal and carrion. Dogs pose a threat to wildlife in the northern areas of the park, where they have taken to hunting antelopes. Dogs are also known to have killed sheep and are a threat to the human population as vectors of rabies, a common disease in Bale Region. Every settlement in the Web Valley has several dogs. We estimated a total of 147 dogs in the survey area, an average of 11 dogs per settlement ( 0.7 dogs per sq $\mathrm{km})$. The presence of large numbers of domestic

Table 3. Estimate of Ethiopian wolf densities in 1990 and 1992 for different habitat types in the Bale Mountains National Park

\begin{tabular}{|c|c|c|c|c|}
\hline \multirow[b]{2}{*}{ Habitat } & \multirow{2}{*}{$\begin{array}{l}\text { Area } \\
(\mathrm{sq} \mathrm{km})\end{array}$} & \multicolumn{2}{|c|}{ Density (individuals /sq km) } & \multirow[b]{2}{*}{ Habitat characterized by } \\
\hline & & 1990 & 1992 & \\
\hline Optimal & 158 & $1.0 / 1.2$ & $0.35 / 0.5$ & $\begin{array}{l}\text { Afro-alpine meadows with short grass and } \\
\text { herbs. Rodent biomass estimated at } \\
3500-4000 \mathrm{~kg} / \mathrm{sq} \mathrm{km}\end{array}$ \\
\hline \multirow[t]{2}{*}{ Good } & 396 & $0.25 / 0.35$ & $0.2 / 0.3$ & $\begin{array}{l}\text { Uniform Helichrysum scrub. Rodent } \\
\text { biomass one-third of optimal habitat }\end{array}$ \\
\hline & 42 & $0.25 / 0.35$ & $0.2 / 0.3$ & $\begin{array}{l}\text { Northern grasslands. Rodent biomass one- } \\
\text { third of optimal habitat }\end{array}$ \\
\hline \multirow[t]{2}{*}{ Marginal } & 521 & $0.1 / 0.2$ & 0.1 & $\begin{array}{l}\text { Heather moorlands. Rodent biomass one- } \\
\text { fifth to one-tenth of optimal habitat. }\end{array}$ \\
\hline & 92 & 0.1 & 0.1 & Barren peaks and lava flows \\
\hline
\end{tabular}


dogs in prime Ethiopian wolf habitat is the most immediate threat faced by the species in BMNP. Domestic dogs may affect wild canid species in three ways: (i) by direct competition and aggression; (ii) by transmitting disease; and (iii) by hybridization.

No information is available on wolf-dog interactions in other Ethiopian wolf populations. However, contact between both species is greater at the lower limits of the species's altitudinal range, and this is likely to increase with growing human density and habitat fragmentation. Wolf packs located at the periphery of a restricted population will be more exposed to contact with domestic dogs. Non-resident females dispersing from centres of high wolf density will face increasing chances of meeting a dog instead of another wolf.

In BMNP dogs roam across wide areas of Ethiopian wolf range and forage on rodents, the wolf's main food resource. Additionally, ungulate carcasses that may become available to carnivores; including those of livestock, are quickly monopolized by dogs. Wolves normally avoid direct contact with dogs: in all 34 antagonistic interactions observed during this study dogs were stronger than wolves and always chased the latter away. Wolves were faster than dogs and managed to escape from the attacks.

The world's largest concentration of Ethiopian wolves in Bale, as well as the other few remaining populations, are potential victims of any epidemic outbreak (see Disease below). In Bale, dogs travel regularly with their owners in and out of the mountain massif and are then in contact with many other dogs attracted to garbage and carrion in villages. These dogs may thus transmit pathogens to their wild relatives.

Within the population of Ethiopian wolf that occupies the Web Valley some animals are unusual in that they have shorter muzzles and ears, more heavily built bodies and atypical coat patterns. Because it was considered possible that these differences may have arisen through hybridization with feral dogs, a detailed analysis of interspecific hybridization and genetic variability in the Ethiopian

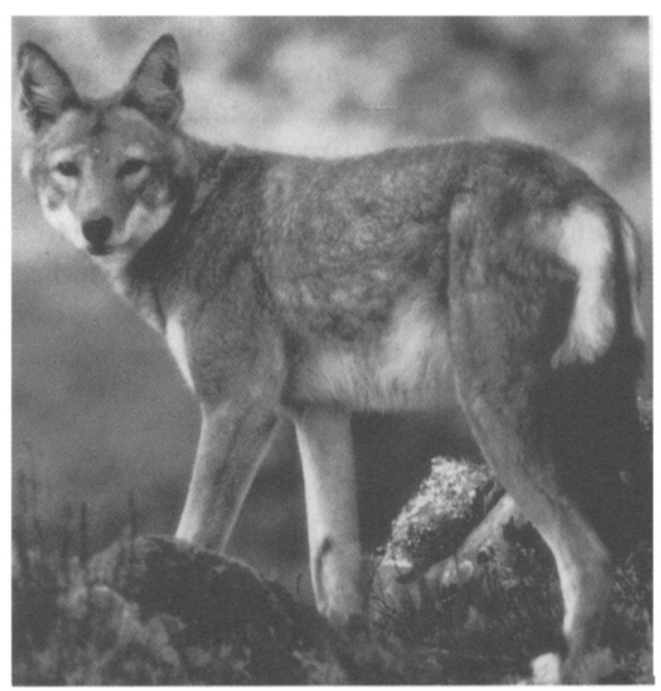

Ethiopian wolves are threatened by habitat loss, persecution, domestic dogs and road traffic (Sillero and Gottelli/WCI).

wolf was initiated. To date, analysis of mitochondrial DNA has contributed no evidence to suggest that introgression with dogs is occurring; other genetic techniques are currently being tested ( $R$. Wayne, pers. comm.).

Canis simensis is closely related to the grey wolf and coyote group (R. Wayne, pers. comm.) thus making hybridization with domestic dogs a distinct possibility. Following hybridization, a population may be affected by a reduction in fitness (in either fertility or viability) known as outbreeding depression (Templeton, 1986).

\section{Persecution by humans}

Until recently the Oromo people living within wolf range in the Bale Mountains have shown remarkable tolerance to the wolves. Four years of close observations on wolf-human interactions in the Web Valley showed that Ethiopian wolves and Oromo pastoralists interacted very little and coexisted peacefully. They did not appear to regard the Ethiopian wolf as a threat to their stock and even occasionally left their sheep unattended during the day. Sixty per cent of 40 heads of family interviewed in areas of high wolf density declared losing at least one lamb from their herd to 
wolves within the last 3 years, but dismissed such losses when compared to damage by spotted hyaenas Crocuta crocuta. Only two cases of predation upon livestock were observed in Bale during this study.

Following the overthrow of the Mengistu's government in May 1991, peaceful coexistence turned into persecution. Automatic weapons sold by deserting soldiers became widely available and Ethiopian wolves and other wildlife became shooting targets. The killing was probably fuelled by old grudges against the park administration. At least six known adult wolves were shot in late 1991. The shooting of a breeding female led to the death of her 3-week-old litter. In another instance two pups perished after their den was plugged with the corpse of a shot wolf. The slaughter subsided after lengthy discussions with the local elders, but the threat is likely to persist until most guns are confiscated.

\section{Disease}

As a species becomes more endangered, their last remaining individuals are likely to be concentrated in a few relict populations. Any of these populations could be eradicated by the sudden outbreak of disease. Many wild populations of canids are subject to disease outbreaks - from distemper in the bat-eared fox Otocyon megalotis in Serengeti, to leishmaniasis in the crab-eating fox Cerdocyon thous of Brazil, and rabies in African wild dog Lycaon pictus (Fanshawe et al., 1991). Artificially high densities of hosts, such as occur when animals are restricted in their movements by reserve boundaries or lack of suitable dispersal habitat, will increase the rates of transmission of all types of direct life-cycle pathogens (Dobson and May, 1986).

Population decline due to disease has been observed in two study populations in Bale. In 1990, 73 per cent of 34 known adults on the Sanetti Plateau were lost ( $n=3$ packs). In 1991 and early 1992, there was a 75 per cent loss in the Web Valley ( $n=48$ adults, five packs). The cause(s) of the death have yet to be determined. Weight loss, empty digestive tracts and diarrhoea were common to all carcasses recovered, suggesting enteric disorders.

The most widespread, and possibly the most dangerous, disease that may affect the Ethiopian wolf is rabies. Rabies is not unknown in the Bale Region (Gottelli and Sillero-Zubiri, 1990). Local residents interviewed in the Web Valley reported a cyclic occurrence of an illness killing many dogs and some Ethiopian wolves every $5-8$ years. Of 15 Ethiopian wolf blood serum samples tested for rabies antibody two were found positive. Additionally, 8 out of 10 samples of unvaccinated domestic dogs tested showed positive results (Mebatsion et al., 1992). Any out-break of this or other canid-related disease could spread via infected dogs to susceptible Ethiopian wolves.

\section{Road kills}

On the Sanetti Plateau an all-weather road runs across 40 kilometres of prime Ethiopian wolf habitat. An average of 26 vehicles (mostly trucks) uses the road every day. At least four wolves have been killed by vehicles since 1988. Two other animals have been shot from the road and another two were left with permanent limps. Similar accidents may occur in other roads across Ethiopian wolf habitat such as the Ankober road and Mehal Meda road in north-east Shoa and the road to Ticho in Arssi.

\section{Conservation}

Brown (1971) discussed the extinction process affecting mammals on mountain tops and proposed large body size and habitat specialization as traits detrimental to long-term survival. The Ethiopian wolf qualifies in both categories. Because its current distribution is limited to isolated pockets of Afro-alpine habitat where small rodents are abundant, the successful conservation of this ecosystem is essential to ensure the survival of the species. Degradation of habitat by grazing and highaltitude agriculture is further fragmenting the habitat available to the species, and making the already habitat-constrained populations susceptible to extinction hazards, such as 
human persecution, outbreeding depression, inbreeding, disease and natural catastrophes.

The Ethiopian wolf population in the Bale Mountains has apparently increased since the BMNP was established, and illustrates the importance of conservation areas to ensure the survival of the species. However, the dramatic decline that population suffered since 1990, the small numbers remaining elsewhere and the fragmentation of its population indicate the vulnerability of this species.

The Ethiopian wolf is now more endangered than it has ever been. Ethiopia and the world stand in extreme likelihood of losing the species if action is not taken now. Every effort should be made to prevent rabies and other diseases from reaching the Ethiopian wolf population, rather than trying to contain the disease after an epidemic. The susceptible population of wild carnivores in the Bale Mountains can be protected by preventing contact with infected animals, i.e. by dog control within and around BMNP, and probably the implementation of a massive oral vaccination programme using baits laced with rabies vaccine (Ginsberg and Macdonald, 1990). The latter technique needs further refinement and testing before it becomes a feasible possibility.

Any future management of Ethiopian wolf populations should concentrate on preserving the species's genetic integrity. Conservation efforts should focus on the total removal of domestic dogs from Ethiopian wolf range and buffer zones around it. Conservation awareness and tolerance towards wildlife will only be possible when direct benefits of conservation reach the local community.

In view of the persisting human impact on its overall distribution and its vulnerability to extinction, the establishment of a captive breeding programme must be undertaken.

\section{Captive breeding}

The aims of captive breeding are to create a genetically pure population safe from the threats faced by wild populations and to produce founder populations for reintroduction programmes. It is an insurance programme for the continuity of the endangered species regardless of crises in its natural habitat. Captive breeding of wild animals can also serve as latter-day 'arks' (gene banks) if wild populations become extinct.

Three approaches are considered to enhance conservation of the Ethiopian wolf: (i) establishment of a captive-breeding facility in Ethiopia, preferably in suitable habitat, (ii) captive breeding at an existing international captive-breeding facility, (iii) conservation of habitat and eventual reintroduction of captive-bred animals.

The in-situ and ex-situ captive-breeding approaches provide different advantages and are mutually supporting, the advantages of each one working to the benefit of the other (Ginsberg and Macdonald, 1990). Imperative to the whole programme is the third component of continued maintenance of the species' natural habitat in Ethiopia.

\section{Conclusions}

In the northern part of their range, Ethiopian wolves may be on the verge of extinction as a result of habitat destruction by increased agricultural practices at high altitudes and overgrazing. However, in north-eastern Shoa, Ethiopian wolves have survived in small relicts of original habitat and in the presence of a high human population. With the probable exception of Simien, remnant wolf populations north-west of the Rift Valley are so small that they may not be viable. To the south, the Arssi population is subject to similar human pressures for pasture and arable land. There are good possibilities of conserving additional areas of Afro-alpine habitat, provided Ethiopia's current attempts to secure peace and stability succeed and more funding becomes available.

Protective measures in the case of the Ethiopian wolf require active efforts to monitor its remaining populations. Conservation priorities must be decided pragmatically with regard to the allocation of resources and manpower, which implies that current conservation efforts should be directed to established conservation areas, i.e. BMNP and Simien 
Mountains National Park, and the global captive-breeding programme. Provided that the Ethiopian authorities step up appropriate park management with increasing support from the international community, the BMNP will remain the best refuge for the survival of these fascinating canids.

\section{Acknowledgments}

The Bale Mountains Research Project is supported by Wildlife Conservation International, New York Zoological Society, under the auspices of the Ethiopian Wildlife Conservation Organisation. We would like to thank Chris Hillman, Derek Yalden and Josh Ginsberg for their helpful comments on a draft of this article. We also extend our thanks to the BMNP staff and Edriss Ebu for their support and friendship.

\section{References}

Bonnefille, R., Roeland J.C. and Guiot, J. 1990. Temperature and rainfall estimates for the past 40,000 years in equatorial Africa. Nature, 346, 347-349.

Brown, J.H. 1971. Mammals on mountain tops: nonequilibrium insular bio-geography. American Naturalist, 105, 467-478.

Brown, L.H. 1964a. A report on the wildlife situation in the Semien mountains of north Ethiopia with special reference to the Walia ibex, Capra walie and the Semien fox, Simenia simensis. Report to WWF, Mimeo, $28 \mathrm{pp}$.

Brown, L.H. 1964b. A report on the mountain nyala Tragelaphus buxtoni, the Semien fox Simenia simensis, and other animals in the Mendebo mountains, Bale Province, Ethiopia. Report to WWF, Mimeo, $13 \mathrm{pp}$.

Delany, M.J. 1972. The ecology of small rodents in tropical Africa. Mammal Rev. 2, 1-42.

Dobson, A. and May, R. 1986. Disease and conservation. In Conservation Biology: The Science of Scarcity and Diversity (ed. M. E. Soulé), pp. 345-365, University of Michigan.

Fanshawe, J.H., Frame, L.H. and Ginsberg, J.R. 1991. The wild dog - Africa's vanishing carnivore. Oryx, 25, 137-146.

Flenley, J. 1979. The Equatorial Rain Forest: A Geological History. Butterworths, London.

Ginsberg, J.R. and Macdonald, D.W. 1990. Foxes, Wolves, Jackals and Dogs. An Action Plan for the Conservation of Canids. IUCN/SSC Canid Specialist Group and Wolf Specialist Group, IUCN, Gland, Switzerland.
Gottelli, D. and Sillero-Zubiri, C. 1990 . The Simien Jackal: Ecology and Conservation. Wildlife Conservation International, New York.

Hillman, J.C. 1986a. Conservation in Bale Mountains National Park, Ethiopia. Oryx, 20, 89-94.

Hillman, J.C. 1986b. Bale Mountains National Park Management Plan. Ethiopian Wildlife Conservation Organisation, Addis Ababa, Ethiopia.

Hurni, H. 1986. Management Plan: Simien Mountain National Park and Surrounding Rural Areas. Wildlife Conservation Organisation. Ministry of Agriculture, Ethiopia.

IUCN, 1990. 1990 IUCN Red List of Threatened Animals. IUCN, Gland, Switzerland and Cambridge, UK.

Kingdon, J. 1990. Island Africa. Collins. London.

Malcolm, J.R. 1987. A recensus of Simien jackals (Canis simensis) in Bale, Ethiopia. Report to Ethiopian Wildlife Conservation Organisation and National Geographic Society. Mimeo.

Mebatsion, T., Sillero-Zubiri, C., Gottelli, D. and Cox, J.H. 1992. Detection of rabies antibody by ELISA and RFFIT in unvaccinated dogs and in the endangered Simien jackal of Ethiopia. J. Vet Med. $\mathrm{B} 39$ (in press).

Mesfin Wolde-Mariam, 1972. An Introductory Geography of Ethiopia. Addis Ababa.

Messerli, B., Hurni, H., Kienholz, H. and Winiger, M. 1977. Bale Mountains: largest Pleistocene mountain glacier system of Ethiopia. INQA Abstracts, Birmingham.

Morris P.A. and Malcolm, J.R. 1977. The Simien fox in the Bale Mountains. Oryx, 14, 151-160.

Scott, H. 1958. Biogeographical research in high Simien. Proc. Linn. Soc. 170, 1-91.

Sillero-Zubiri, C. and Gottelli, D. 1991. Conservation of the endemic Ky Kebero (Canis simensis). Walia, 13, 35-46.

Templeton, A. 1986. Coadaptation and outbreeding depression. In Conservation Biology: The Science of Scarcity and Diversity (ed M.E. Soulé), pp. 105-116. University of Michigan.

Yalden D.W. 1983. The extent of high ground in Ethiopia compared to the rest of Africa. Sinet: Eth. J. Sci. 6, 35-38.

Yalden D.W., Largen, M.J. and Kock, D. 1980. Catalogue of the mammals of Ethiopia. 4. Carnivora. Monit. Zool. Ital. NS Suppl XIII(8), 169-272.

Dada Gottelli and Claudio Sillero-Zubiri, Wildlife Conservation International, New York Zoological Society, Bronx 10460, USA, and

Wildlife Conservation Research Unit, Zoology Department, South Parks Road, Oxford OX1 3PS, UK. 